\title{
PRIMENA METODE KONTROLISANOG EKSPERIMENTAU ANALIZI PONAŠANJA POTROŠAČA ELEKTRIČNE ENERGIJE
}

\author{
Sanja Filipović1, *, \\ Mirjana Radovanović 2
}

1 Univerzitet Singidunum, Beograd, Srbija

2Univerzitet Educons, Sremska Kamenica, Srbija
Odgovorno lice:

Sanja Filipović

e-pošta:

sfilipovic@singidunum.ac.rs
Rezime:

Unapređenje energetske efikasnosti u domaćinstvima je jedan od prioriteta Srbije, s obzirom da se električna energija u domaćinstvima neracionalno troši, a domaćinstva imaju dominantno učešće od oko $51 \%$ u finalnoj potrošnji električne energije. Kako bi se unapredila energetska efikasnost, neophodno je definisati ključne faktore koji utiču na ponašanje potrošača. Na ponašanje potrošača, pored cenovnih, utiče i čitav niz necenovnih faktora. Polazeći od činjenice da je cena električne energije u Srbiji najniža u Evropi, u ovom radu fokus je na necenovnim faktorima. Cilj ovog istraživanja je da utvrdi da li informisanje domaćinstava o jednostavnim načinima za uštedu električne energije doprinosi promeni njihovog ponašanja. Istraživanje je sprovedeno primenom metode kontrolisanog eksperimenta što je podrazumevalo definisanje eksperimentalne i kontrolne grupe na uzorku od 330 domaćinstava. Istraživanje je pokazalo da u situaciji kada je cena električne energije veoma niska, informacije o uštedi energije nemaju značajan uticaj na promenu ponašanja potrošača.

Ključne reči:

cena električne energije, potrošnja, metod kontrolisanog eksperimenta.

\section{UVOD}

Evropska unija aktivno promoviše tranziciju energetike na troškovno-efikasnom principu, a sve u cilju da svojim građanima omogući sigurno, pouzdano i održivo snabdevanje energijom. Energetska i klimatska politika Evropske unije za vremenski period do 2030. godine ima jasno definisana tri ključna cilja: a) unapređenje energetske efikasnosti za 20\%; b) smanjenje emisije gasova staklene bašte za najmanje $40 \%$ u odnosu na nivo emisije iz 1990. godine i c) povećanje učešća obnovljivih izvora energije u ukupnoj potrošnji energije za 30\%. U novembru 2016. godine, Evropska komisija je predložila energetski paket (Clean Energy Package For All Europeans) kojim se reguliše osam oblasti, gde posebno mesto ima regulacija tržišta električne energije i regulativa vezana za unapređenje energetske efikasnosti.

U ovom radu fokus istraživanja biće isključivo na faktorima koji podstiču efikasno korišćenje električne energije u domaćinstvima. U cilju unapređenja efikasne potrošnje električne energije u domaćinstvima 
koriste se razne vrste mera koje se generalno mogu svrstati u grupu finansisjkih mera (npr. subvencije za kupovinu energetski efikasnih kućnih aparata) i nefinansijskih mera koje više imaju informativnu i edukativnu ulogu (npr. edukacija o efikasnoj upotrebi električne energije). Utvrđivanje efekata ovih podsticajnih mera u velikoj meri može doprineti definisanju adekvatne politike unapređenja energetske efikasnosti u domaćinstvima.

Istraživanje uticaja promene cene električne energije na promenu nivoa potrošnje električne energije ima ogroman značaj kako bi se definisala adekvatna politika podsticanja efikasne potršnje. U literaturi se može naći dosta istraživanja koja su se bavila analizom uticaja cena električne energije na promenu nivoa potrošnje električne energije u domaćinstvima $[1,2]$. U skladu sa empirijskim rezultatima, opšte je poznato da je električna energija visoko cenovno neelastična, odnosno da će procentualni rast cene električne energije biti praćen manjim procentualnim padom u traženoj količini. Razlog tome je činjenica da je električna energija jedno od osnovnih dobara bez koga se teško može zamisliti savremeno društvo.

Jacobsen [3] tvrdi da, u uslovima kada postoje neiskorišćene mogućnosti za ulaganje, rast cene električne energije za potrošače ne znači gubitak po svaku cenu. Štaviše, potrošači mogu biti na dobitku ukoliko ih rast cene električne energije podstakne da ulažu u energetski efikasne uređaje. Nasuprot tome, ako potrošači reaguju na rast cene električne energije tako što smanjuju potrošnju električne energije, gubitak može biti znatno veći, apstrahujući tako sve koristi od redukovanja eksternalija nastalih potrošnjom električne energije (primer eksternalija može biti emisija $\mathrm{CO}_{2}$ u slučaju proizvodnje električne energije na bazi fosilnih goriva). Prisustvo anomalija u ponašanju potrošača može dovesti do toga da se potrošači ne ponašaju u skladu sa očekivanjima (npr. nezainteresovanost za štednju električne energije), odnosno da rast cene ne mora nužno značiti i doslednu primenu principa minimizacije troškova [4]. Otuda, finansijski podsticaji bazirani na rastu cena električne energije ne moraju nužno da podstiču investicije u energetski efikasne uređaje u domaćinstvu [5].

Kako je analiza uticaja cene električne energije dosta zastupljena u literaturi, predmet ovog istraživanja biće analiza uticaja necenovnih faktora, a pre svega, uticaja informacija kako se električna energija može efikasno i bez velikih ulaganja uštedeti u domaćinstvima. Istražvanje je sprovedeno u Srbiji na uzorku od 330 domaćinstava i u ovom radu su predstavljeni preliminarni rezultati istraživanja. Dodatni motiv za analizu necenovnih faktora je činjenica da Srbija (gde je terensko istraživanje sprovedeno) ima ubedljivo najnižu cenu električne energije u Evropi.

Cilj istraživanja je da se utvrdi koliki značaj imaju korisne informacije za uštedu električne energije na potrošnju u domaćinstvu. Istraživanje je sprovedeno primenom metode kontrolisanog eksperimenta (Randomized Control Trials, RCT). Činjenica da se u ovom istraživanju koristi RCT metod, čini ovo istraživanje jedinstvenim s obzirom da koliko je poznato autorima ovaj metod istraživanja nije korišćen za te svrhe u Srbiji. Inače RCT method se tek odnedavno koristi u svetu za ispitivanje faktora koji utiču na ponašanje potrošača, a njegova primena je bila dominantna u medicinskim naukama i psihologiji.

Drugi bitan naučni doprinos ovog istraživanja se ogleda u činjenici da je ono sprovedeno na uzorku od 330 domaćinstava, što u odnosu na sprovedena istraživanja ove vrste u svetu nije zanemarljiv uzorak. Ranije studije iz ove oblasti su bile bazirane na malim pilot istraživanjima kod kojih je bilo teško odrediti uzročne faktore i generalizovati zaključke $[6,7]$. Tek nedavno su sprovedena empirijska istraživanja na relativno većim uzorcima uz primenu RCT metode $[8,9,10]$. Istraživanja su pokazala da cene i informacije, kao i faktori koji utiču na ponašanje potrošača (npr. društvene norme, standardi i obrasci ponašanja) imaju značajan uticaj na potrošnju električne energije u domaćinstvu.

Rad je struktuiran tako da, pored uvoda ima još pet tematski povezanih celina. U drugom delu rada dat je kratak pregled literature, odnosno rezultata relevantnih istraživanja u ovoj oblasti. U trećem delu rada je predstavljena metodologija istraživanja. Četvrti deo rada je posvećen analizi rezultata i diskusiji, dok su u poslednjem zaključnom delu sumirani nalazi istraživanja.

\section{PREGLED LITERATURE}

Tek nedavno je RCT metod počeo da se koristi u studijama koje imaju za predmet istraživanja očuvanje resursa i tumačenje eksternalija u životnoj sredini. U poslednjih nekoliko godina su sprovedena istraživanja na bazi RCT metode koja imaju za cilj da utvrde efikasnost intervencija ( $u$ vidu edukativnih informacija) $\mathrm{u}$ na nivo potrošnje električne energije u domaćinstvima. Tako je Allcott u svom istraživanju iz 2011. godine [11] pokazao da pružanje informacija o efikasnim načinima uštede električne energije može smanjiti potrošnju na nivou domaćinstva od 2\%. Druga istraživanja [12] su 
pokazala da efekti korisnih instrukcija mogu biti najveći u domaćinstvima koja inače imaju visok nivo potrošnje, ali da je bitno koliko se često instrukcije ponavljaju.

U jednom pilot istraživanju iz 2013. godine, Houde [13] je pokazao da prosečna ušteda potrošnje električne energije može biti i 7\%, ali pod uslovom da domaćinstva imaju tzv. pametne uređaje koji automatski mere potrošnju u realnom vremenu. Jedno drugo empirijsko istraživanje [14] je pokazalo da će se efekat instrukcija tokom vremena smanjivati tako da će nakon četiri nedelje efekat instrukcija biti gotovo neznatan.

Istraživanje koje su sproveli Allcott i Rogersa [8] pokazalo je da domaćinstva čim prime izveštaj o potrošnji odmah smanjuju svoju potrošnju, ali nedugo zatim ovaj efekat gubi na značaju i domaćinstva se već posle nekoliko nedelja vraćaju prvobitnim navikama i tako završavaju na prvovobitnom nivou potrošnje električne energije.

Upravo ta istraživanja koja su pokazala da se efekat informacije smanjuje s protokom vremena su podstakla istraživanje grupe autora [15] koji su imali za cilj da definišu da li je smanjenje potrošnje energije nastalo kao posledica usvanjanja informacija (tzv. efekat učenja) ili je do smanjenja u potrošnji energije došlo usled toga što su stalno pred sobom imali informaciju o nivou potrošnje (npr. merač koji pokazuje uštede). To istraživanje je pokazalo da je efekat učenja bio dominantniji, ali da je imao opadajući značaj tokom vremena. U skladu sa tim, autori su zaključili da medijske informativne i edukativne kampanje imaju veći efekat od instaliranja raznih merača u domaćinstvima.

Do sada nisu sprovedena neka značajnija istraživanja na većem uzorku koja bi na sistemskom nivou analizirala koliko je bitna učestalost informacija na ponašanje potrošača, niti koliko sama dužina eksperimenta utiče na istrajnost domaćinstava u primeni instrukcija za energetske uštede. Taubinsky [4] je u svom istraživanju pokazao da se istrajnost u primeni instrukcija može podstaći tako što će se instrukcije ponavljati kroz razne medijske kampanje. Do sličnih nalaza su došli Allcott $i$ Rogers [14] koji su ukazali da razni izveštaji o potrošnji imaju samo kratkotrajan efekat.

Svi ti nalazi su dali podsticaj da se sprovede ovo istraživanje u Srbiji bazirano isključivo na širenju korisnih edukativnih informacija o načinima uštede električne energije u domaćinstvu koji ne zahtevaju nikakva dodatna ulaganja. Naravno, pošlo se i od činjenice da domaćinstva u Srbiji generalno ne raspolažu sa meračima za potrošnju električne energije (tzv. brojila koja očitavaju potrošnju svakog kućnog aparata u domaćinstvu).

\section{METODOLOGIJA ISTRAŽIVANJA}

U ovom istraživanju terenski eksperiment je razvijen u skladu sa karakteristikama nacionalnog tržišta električne energije. Tržište električne energije u Srbiji još nije potpuno liberalizovano i cene električne energije su regulisane. Domaćinstva mogu da biraju između nekoliko registrovanih dobavljača električne energije, ali ipak zbog konkurentne cene domaćinstva se opredeljuju za tržišno dominantnog proizvođača električne energije (javno preduzeće Elektroprivreda Srbije, EPS). U Srbiji ne postoje tzv. pametna brojila, tako da podatke o potrošnji električne energije i dalje beleže operateri koje EPS angažuje. Operateri na mesečnom nivou posećuju domaćinstva i prave evidenciju o potrošnji, na osnovu koje se sastavlja mesečni račun za potrošnju električne energije.

U Srbiji domaćinstva imaju dominantno učešće od $51 \%$ u ukupnoj potrošnji električne energije. Potrošnja električne energije u domaćinstvima nije efikasna između ostalog i zbog toga što se električna energija koristi za grejanje. Podaci Eurostata pokazuju da domaćinstava u Srbiji troši gotovo pet puta više električne energije po jedinici bruto domaćeg proizvoda od proseka zemalja članica Evropske unije. Budući da se proizvodnja električne energije u Srbiji uglavnom zasniva na termoelektranama na lignit (termoelektrane čine $73 \%$ ukupne proizvodnje električne energije), postoji visok nivo emisije $\mathrm{CO}_{2}$. Nivo emisije $\mathrm{CO}_{2}$ po stanovniku je na nivou proseka Evropske unije, ali je emisija po jedinici bruto domaćeg proizvoda u Srbiji skoro šest puta veća.

Vrlo bitna je činjanica da je cena električne energije u Srbiji najniža u Evropi. Poređenja radi, prema podacima Eurostata za kraj prvog polugodišta 2018. godine, prosečna cena električne energije (uključujući poreze i takse) za domaćinstva na nivou Evropske unije je iznosila 20,53 euro centi, dok je cena električne energije za domaćinstvo u Srbiji iznosila 7,05 euro centi.

Imajući u vidu da su cene električne energije u Srbiji najniže u Evropi, preliminarna hipoteza ovog istraživanja bila je da je niska cena električne energije za domaćinstava glavni razlog zašto se električna energija ne koristi racionalno. Polazeći od te pretpostavke, ideja ovog istraživanja je bila da se analizira da li informacije o uštedi energije mogu da promene ponašanje potrošača u Srbiji.

Polazna hipoteza istraživanja je da informacije o uštedi energije predstavljaju efikasno sredstvo za menjanje navika potrošača, odnosno da će korisne informacije uticati na efikasnije ponašanje potrošača i smanjenje 
potrošnje električne energije u domaćinstvima. Istraživanje je urađeno sa ciljem da se utvrdi uticaj instrukcija za uštedu energije na potrošnju električne energije u domaćinstvu, odnosno da li korisne informacije mogu da promene navike potrošača u Srbiji.

Uzorak istraživanja se sastojao od 330 domaćinstava sa teritorije Beograda koja imaju slične nivoe prosečne potrošnje električne energije. Da bi se postigla jednaka zastupljenost domaćinstava koja koriste različite metode za zagrevanje, ukupan uzorak je podeljen na tri pod-uzorka:

1. Prvi pod-uzorak čine domaćinstva koja žive u zgradama u kojima postoji daljinski sistem grejana (domaćinstva sa lokaliteta Novi Beograd),

2. Drugi pod-uzorak čine domaćinstva koja žive u manjim i starijim zgradama bez daljinskog grejanja, tako da ova domaćinstva uglavnom koriste električnu energiju za zagrevanje (stari centar Beograda) i

3. Treći pod-uzorak čine domaćinstva koja žive u predgrađu, uglavnom u kućama i koriste različite energetne za zagrevanje životnog prostora (struja, drvo, ugalje, itd.).

Ova podela je važna jer uređaji koji se koriste za zagrevanje na električnu energiju često su najveći potrošači u domaćinstvu i stoga mogu uticati na spremnost domaćinstava da primenjuju instrukcije za uštedu energije. Za svaki pod-uzorak, domaćinstva su nasumično izabrana. Nakon toga, prešlo se u fazu terenskog istraživanja što je podrazumevalo posetu domaćinstava i informisanje o samom istraživanju. Domaćinstva koja su pristala da učestvuju su nasumično podeljena u eksperimentalnu grupu i kontrolnu grupu (50:50).

Kontrolna grupa nije bila izložena "tretmanu" i ova grupa je korišćena za poređenje sa eksperimentalnom grupom. Učesnici u eksperimentalnoj grupi su dobili brošuru sa uputstvima za uštedu energije. Takva intervencija je korišćena kako bi se povećala svest potrošača i ispitalo da li usvajanje novih obrazaca potrošnje ima stvarni uticaj na smanjenje potrošnje. Domaćinstva u eksperimentalnoj grupi trebalo je da usvoje i primene jednostavne instrukcije za uštedu energije date $u$ brošuri. Ta uputstva za uštedu električne energije u domaćinstvima odnosila su se na efikasnije korišćenje aparata za svakodnevnu upotrebu (grejanje, bojler, veš mašina, šporet, frižider i osvetljenje u stanovima). Promenom navika u korišćenju kućnih aparata, moguće su određene uštede. Očekivani uticaj takve intervencije odražava usvajanje i sprovođenje datih uputstava za domaćinstva tokom eksperimenta.
Takav vid intervencija (instrukcija) su koristili i drugi autori. Abrahamse [15] je isto u svom istraživanju koristio instrukcije u vidu informacija o mogućnostima uštede energije za domaćinstva što može dovesti do uštede energije jer su potrošači stekli određena saznanja. Potrošnja potrošača u eksperimentalnoj grupi je poređena sa domaćinstvima u kontrolnoj grupi na mesečnom nivou. Ovakvo poređenje potrošnje električne energije između eksperimentalne i kontrolne grupe omogućava nam da odredimo efekat informacija o promeni ponašanja, a samim tim i potrošnji električne energije.

Istraživanje je sprovedeno tokom tromesečnog perioda i obuhvatio je analizu potrošnje električne energije u periodu februar - april 2018. godine. Primenom eksperimentalne i kontrolne grupe eliminiše se problem sezonskog efekta u potrošnji.

\section{REZULTATI I DISKUSIJA}

Na početku istraživanja, polazna pretpostavka je bila da cenovni podsticaji neće biti efikasni u ovom istraživanju zbog činjenice da je cena električne energije u Srbiji najniža u Evropi.

Politika cena električne energije mora se voditi pravilom da cene moraju biti iznad nivoa marginalnih troškova proizvodnje jer u suprotnom cene šalju pogrešne signale što se negativno odražava na nivo potrošnje (neracionalna potrošnja) ili na pogrešne investicione odluke [16]. Formiranje cena u realnom vremenu može da ispravi ovu distorziju, ali efekat cena na ukupnu potrošnju i na investicije u energetski efikasne tehnologije je upitan [17].

U ovom istraživanju pretpostavljeno je da niska cena električne energije može biti ključni razlog visoke i neefikasne potrošnje električne energije u domaćinstvima. Umesto izbora cena, u ovom istraživanju postavljena je hipoteza istraživanja da informacije o uštedi energije predstavljaju efikasno sredstvo za uticj na energetsko ponašanje domaćinstava u Srbiji i smanjenje potrošnje električne energije.

Međutim, rezultati istraživanja nisu potvrdili ovu hipotezu. Prvi pod-uzorak koji čine domaćinstva koja imaju pristup daljinskom grejanju (ova grupa domaćinstava ima inače najniži nivo potrošnje električne energije) su zabeležila najniži nivo promene potrošnje električne energije između eksperimentalne i kontrolne grupe. U februaru je prosečna potrošnja domaćinstava u eksperimentalnoj grupi i kontrolnoj grupi iznosila $349 \mathrm{kWh}$, odnosno 345 kWh. U martu je kontrolna grupa zabeležila pad potrošnje (prosečna potrošnja električne energije domaćinstava u eksperimentalnoj grupi bila je $366 \mathrm{kWh}$ u odnosu na 
$369 \mathrm{kWh} u$ kontrolnoj grupi), dok je u aprilu nivo potrošnje u obe grupe bio na istom nivou ( $322 \mathrm{kVh}$ ).

U drugom pod-uzorku koji čine domaćinstava koja dominantno koriste električnu energiju za grejanje (centar Beograda), prosečna potrošnja električne energije je najveća. Posmatrajući kontrolnu grupu pre početka eksperimenta, prosečna mesečna potrošnja je bila 2,5 puta veća nego u domaćinstvima sa daljinskim grejanjem. U ovom pod-uzorku, eksperimentalna grupa je tokom čitavog eksperimentalnog perioda zabeležila niži nivo potrošnje električne energije nego u kontrolnoj grupi. U februaru je prosečna potrošnja domaćinstava u eksperimentalnoj grupi i kontrolnoj grupi iznosila $872 \mathrm{kWh}$, odnosno $979 \mathrm{kWh}$. U martu je zabeležen pad potrošnje električne energije - prosečna potrošnja električne energije u eksperimentalnoj grupi iznosila je $732 \mathrm{kWh}$, dok je prosečna potrošnja električne energije u kontrolnoj grupi iznosila $842 \mathrm{kWh}$. U aprilu je nivo potrošnje u eksperimentalnoj grupi iznosio $230 \mathrm{kWh}$, dok je u kontrolnoj grupi bio $343 \mathrm{kWh}$.

U trećem pod-uzorku koji čine domaćinstva koja koriste različite izvore energije za grejanje (predgrađe Beograda), eksperimentalna grupa je zabeležila niži nivo potrošnje električne energije od prosečne potrošnje domaćinstava u kontrolnoj grupi tokom celog posmatranog perioda. U februaru je prosečna potrošnja domaćinstava u eksperimentalnoj grupi iznosila 656 $\mathrm{kWh}$, dok je kontrolna grupa imala prosečnu potrošnju električne energije od $710 \mathrm{kWh}$. U martu je prosečna potrošnja domaćinstava u eksperimentalnoj grupi iznosila 715 kWh i 743 kWh u kontrolnoj grupi. Prosečna potrošnja domaćinstava u eksperimentalnoj grupi i kontrolnoj grupi u aprilu je iznosila $503 \mathrm{kWh}$, odnosno 550 kWh. Na slici 1. prikazani su rezultati prosečne potrošnje električne energije u obe grupe za tri stratuma tokom posmatranog perioda.

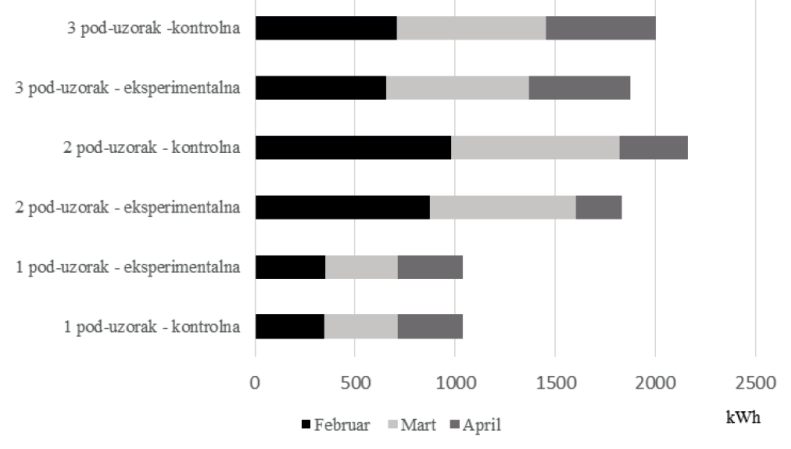

Grafikon 1. Prosečna potrošnja električne energije na nivou uzorka

Izvor: proračun autora.
Ovo istraživanje je pokazalo da se nivo potrošnje električne energije nije značajno razlikovao između kontrolne i eksperimentalne grupe, iako je eksperimentalna grupa dobila instrukcije o tome kako poboljšati energetsku efikasnost u svom domaćinstvu. Pored toga, važno je istaći da se svi članovi eksperimentalne grupe bili kontaktirani telefonom svakog meseca i tom prilikom su bili pitani da li se pridržavaju uputstava. Najveće odstupanje u potrošnji električne energije između eksperimentalne i kontrolne grupe evidentno je u uzorku domaćinstava koja koriste električnu energiju za grejanje (drugi pod-uzorak). Stoga se može zaključiti da je ova grupa domaćinstava bila najviše zainteresovana za smanjenje potrošnje električne energije što je u skladu i sa nalazima drugih autora.

\section{ZAKLJUČAK}

Istraživanje je pokazalo da u situaciji kada su cene električne energije niske, informacije o uštedama električne energije nemaju veliki uticaj na ponašanje potrošača. Na osnovu analize prosečne potrošnje u kontrolnoj i eksperimentalnoj grupi (sezonski efekat se gubi jer se koristi kontrolna i eksperimentalna grupa) može se videti da nisu prisutna značajnija odstupanja, odnosno potrošači nisu spremni da samo na osnovu informacija o uštedama menjaju svoje navike u potrošnji električne energije.

Pa ipak, terensko istraživanje je pokazalo da domaćinstva u Srbiji još uvek nemaju dovoljno informacija o efikasnim načinima za uštedu električne energije, niti imaju dovoljno znanja o savremenim tehnološkim uređajima koji su troškovno efikasniji u odnosu na tradicionalne uređaje koji se koriste za grejanje u domaćinstvima. Činjenica je da domaćinstva imaju dominantno učešće u strukturi finalne potrošnje električne energije, kao i da velika većina električnu energiju neefikasno koristi. Najveći problem predstavlja praksa da se usled relativno niske cene, električna energija u mnogim domaćinstvima koristi za grejanje. Razlog tome je nerazvijena infrastruktura, odnosno mogućnosti za upotrebu drugih izvora za grejanje (npr. nerazvijen sistem za daljinsko grejanje, nedovoljno razgranata mreža za gasifikaciju, nedostatak podsticaja za uvođenje tehnološki efikasnijih sistema za grejanje u domaćinstvima, itd.). Bolja informisanost i podsticaji domaćinstvima za ulaganja u tehnologije za proizvodnju električne energije na bazi obnovljivih izvora (npr. solarni paneli), mogli bi promenitu tradicionalnu sliku prosečnog potrošača u Srbiji. 
Najveće ograničenje ovog istraživanja je bilo da se obezbedi da domaćinstava koja čine eksperimentalnu i kontrolnu grupu, na samom početku, pre nego što se i počne sa eksperimentom, imaju isti nivo potrošnje električne energije. I pored toga što je napravljen uzorak od domaćinstva koja imaju prilično ujednačenu potrošnju na nivou uzorka, gotovo je bilo nemoguće napraviti podelu na eksperimentalnu i kontrolnu grupu tako da nivo potrošnje pre početka istraživanja bude isti. Kako je taj kriterijum bio ispunjen jedino u prvom slučaju (domaćinstva koja imaju daljinsko grejanje), čini se da su ti podaci i najpouzdaniji.

\section{ZAHVALNOST}

Istraživanje je rađeno za potrebe Enable projekta (Enabling the Energy Union through understanding the drivers of individual and collective energy choices in Europe) koje je finansirala Evropska komisija u okviru Horizon programa.

\section{LITERATURA}

[1] M. Filippini, "Short- and long-run time-of-use price elasticity in Swiss residential electricity demand", Energy Policy 39, 2011, pp. 5811-5817.

[2] M. Lijesen, "The real-time price elasticity of electricity", Energy Economics Volume 29, Issue 2, 2007, pp. 249-258.

[3] G. D. Jacobsen, "Do energy prices influence investment in energy efficiency? Evidence from energy star appliances," Journal of Environmental Economics and Management 74, 2015, pp. 94-106.

[4] D. Taubinsky, "From intentions to actions: A model and experimental evidence of inattentive choice", 2013, Work Paper.

[5] K. Gillingham, R. G. Newell, K. Palmer, "Energy efficiency economics and policy", Annual Review of Resource Economics 1(1), 2009, pp. 597-620.

[6] A. Faruqui, S. Sergici, "Household response to dynamic pricing of electricity: a survey of 15 experiments", Journal of Regulatory Economics 38(2), 2010, pp. 193-225.
[7] A. Faruqui, S. Sergici, A. Sharif, "The impact of informational feedback on energy consumption - A survey of the experimental evidence", Energy 35(4), 2010, pp. 1598-1608.

[8] H. Allcott, T. Rogers, “The short-run and long-run effects of behavioral interventions: Experimental evidence from energy conservation", The American Economic Review 104(10), 2014, pp. 3003-3037.

[9] J. A. List, R. D. Metcalfe, M. K. Price, F. Rundhammer, "Harnessing Policy Complementarities to Conserve Energy: Evidence from a Natural Field Experiment", Technical report, 2017, National Bureau of Economic Research.

[10] K. Jessoe, D. Rapson, "Knowledge is (less) power: Experimental evidence from residential energy use", The American Economic Review 104(4), 2014, pp. 1417-1438.

[11] H. Allcott, "Social norms and energy conservation", Journal of Public Economics 95(9), 2011, pp. 10821095.

[12] I. Ayres, A. S. Raseman, A. Shih, "Evidence from two large field experiments that peer comparison feedback can reduce residential energy usage", Journal of Law, Economics, and Organization, 29 (5), 2012, pp. 992-1022.

[13] S. Houde, A. Todd, A. Sudarshan, J. A. Flora, K. C. Armel, "Real-time feedback and electricity consumption: A field experiment assessing the potential for savings and persistence", The Energy Journal 34(1), 2013, pp. 87-102.

[14] J. Lynham, K. Nitta, T. Saijo, N. Tarui, "Why does real-time information reduce energy consumption?", Energy Economics 54, 2016, pp. 173-181.

[15] W. Abrahamse, L. Steg, C., Vlek, T. Rothengatter, "A review of intervention studies aimed at household energy conservation". Journal of Environmental Psychology 25 (3), 2005, pp. 273-291.

[16] P. L. Joskow, C. D. Wolfram, "Dynamic pricing of electricity", The American Economic Review 102(3), 2012, pp. 381-385.

[17] K. Gillingham, R. G. Newell, K. Palmer, "Energy efficiency economics and policy", Annual Review of Resource Economics 1(1), 2009, pp. 597-620. 